\title{
AKUNTAN DI ERA DIGITAL: \\ PENDEKATAN TAM (TECHNOLOGY ACCEPTANCE MODEL) PADA SOFTWARE BERBASIS AKUNTANSI
}

\author{
Arya Samudra Mahardhika S.E., Ak., M.Sc \\ Program Studi Akuntansi \\ STIE Putra Bangsa \\ aryamahardhika1988@gmail.com
}

\begin{abstract}
ABSTRAK
The purpose of this research was to investigate the intention determining factor of novice accountant in using MYOB software through Davis'Technology Acceptance Model (TAM) approach. Respondent of this research was 47 novice accountants who had experience with MYOB. The hypothesis of this research was analyzed using multiple regression using SPSS. The results showed that perceived usefulness is the only determining factor of intention.
\end{abstract}

Keywords: perceived ease of use, perceived usefulness, intention to use

\section{PENDAHULUAN}

\section{Latar Belakang}

Penggunaan teknologi dalam dunia bisnis bukan merupakan suatu hal yang baru, terutama di era revolusi industri 4.0 atau digitalisasi. Teknologi merupakan suatu komponen penting dalam sistem informasi yang diharapkan dapat menghasilkan informasi secara cepat dan tepat (Winarni dan Rahmawati, 2015), sehingga perkembangan sistem informasi berbasis komputer berkembang dengan sangat pesat.

Kerumitan transaksi bisnis memerlukan adanya teknologi yang memungkinkan penggunanya untuk mengelola informasi akuntansi secara tepat, relevan dan akurat (Lucyanda, 2010). Penggunaan teknologi menjadi keunggulan kompetitif bagi pencapaian kerja seorang akuntan (Gögüş dan Özer, 2014) yang secara langsung maupun tidak langsung juga berdampak pada pencapaian organisasi secara keseluruhan.

Menyadari pentingnya teknologi dalam dunia bisnis digital, pengenalan terhadap teknologi perlu dilakukan sedini mungkin dengan harapan tercipta akuntan-akuntan yang kompeten. Integrasi penggunaan komputer dalam pengajaran akuntansi merupakan salah satu cara sederhana dalam rangka memperkenalkan mahasiswa akuntansi, yang merupakan calon akuntan, kepada pembukuan yang terkomputerisasi. Perangkat lunak (software) akuntansi yang paling umum digunakan sebagai media pembelajaran adalah MYOB (Mind Your Own Business), sebuah aplikasi akuntansi berbasis komputer yang diperuntukkan bagi usaha kecil menengah (UKM) untuk mengotomatisasikan pembukuan secara lengkap, cepat, akurat, dan terpadu.

Penerapan suatu teknologi informasi berbasis komputer membutuhkan perangkat keras (hardware), perangkat lunak (software) dan pengguna (brainware) yang saling terintegrasi dengan baik (Bodnar dan Hapwood, 1995). Teknologi dapat diibaratkan sebagai dua sisi mata uang, di satu sisi dapat mendatangkan manfaat yang positif namun di sisi lain dapat mengakibatkan kegagalan yang disebabkan oleh ketidaksiapan penggunanya (Rustiana, 2006), sehingga perlu diperhatikan penerimaan dan penolakan pengguna terhadap suatu teknologi sebelum teknologi tersebut digunakan (Juniarti, 2001).

Indriantoro (2000) menyatakan bahwa penerapan teknologi informasi di suatu organisasi mendorong terjadinya perubahan revolusioner individu dalam bekerja dan dalam konteks penggunaan komputer, sehingga 
keberterimaan suatu teknologi bagi pengguna dan niat mereka untuk tetap menggunakan teknologi tersebut merupakan hal yang penting untuk diperhatikan.

Berdasarkan uraian di atas, penelitian ini bertujuan untuk menguji persepsi calon akuntan terhadap penggunaan software MYOB dengan menggunakan pendekatan TAM (Technology Acceptance Model) dan TPB (Theory of Planned Behavior) pada calon akuntan dan akuntan di Kebumen dengan pertimbangan bahwa software MYOB sesuai digunakan pada kegiatan bisnis di Kebumen yang didominasi oleh UKM.

\section{TINJAUAN PUSTAKA}

\section{TAM (Technology Acceptance Model)}

TAM (Technology Acceptance Model) merupakan sebuah model yang dikembangkan oleh Davis (1989), merupakan model yang paling populer digunakan pada penelitianpenelitian yang terkait teknologi informasi (Surendran, 2012). TAM merupakan adaptasi dari TRA (Theory of Reasoned Action), yaitu teori tindakan yang berdasar bahwa premis bahwa reaksi dan persepsi seseorang terhadap suatu hal akan menentukan sikap dan perilaku orang tersebut (Fishben dan Ajzen, 1975 dalam Dewayanto, 2011).

TAM bertujuan untuk menjelaskan faktorfaktor luar (eksternal) dari perilaku pengguna teknologi informasi terhadap penerimaan teknologi tersebut. Vankatesh dan Davis (2000) menyatakan bahwa perilaku individu dalam menggunakan suatu teknologi informasi dijelaskan oleh TAM menggunakan dua aspek, yaitu a.) manfaat yang dirasakan (perceived usefulness) yang didefinisikan sebagai persepsi seorang individu bahwa kinerjanya akan meningkat setelah ia menggunakan teknologi informasi (Thompson, 1991 dalam Lucyanda, 2010) dan b.) kemudahan penggunaan (perceived ease of use) yang dapat diartikan sebagai persepsi seorang individu bahwa ia dapat menggunakan suatu teknologi informasi tanpa memerlukan banyak upaya (effortless).

\section{Intention to Use}

Penerimaan penggunaan teknologi informasi baik secara individu maupun kelompok bergantung pada penggunaan sistem teknologi informasi tersebut. Apabila pengguna menyakini bahwa dengan menggunakan teknologi tersebut dapat meningkatkan kinerja individu atau organisasi, maka mereka akan memiliki kecenderungan lebih untuk dapat menerima teknologi informasi tersebut (Igabria, 1994 dalam Lucyanda, 2010).

Ajzen (1995) dalam Lucyanda (2010) menyatakan bahwa intention mengacu pada tujuan individu untuk melakukan berbagai perilaku yang beragam dan dapat dipertimbangkan sebagai alasan khusus dalam terhadap keyakinan. Intention adalah suatu kemungkinan di mana seorang individu akan melakukan suatu hal berdasarkan subjektivitasnya.

\section{Hubungan Perceived Ease of Use dan Perceived Usefulness}

Perceived Ease of Use merupakan tingkatan yang mencerminkan keyakinan pengguna bahwa suatu sistem informasi dapat dengan mudah dipahami dan digunakan tanpa membutuhkan banyak usaha. Sistem yang lebih sering digunakan menunjukkan bahwa sistem tersebut sering digunakan, lebih mudah dikenal dan lebih mudah digunakan bagi pengguna (Nasution, 2004). Seorang individu akan merasa bahwa suatu sistem informasi bermanfaat apabila ia merasa bahwa ia dapat menjalankan sistem tersebut dengan mudah.

Penelitian yang dilakukan oleh Saade et al. (2007) dan Tangke (2004) menemukan bahwa perceived ease of use berpengaruh positif terhadap perceived usefulness. Berdasarkan argument dan hasil penelitian terdahulu, maka hipotesis yang diajukan dalam penelitian ini:

$\mathbf{H}_{1}$ : Perceived ease of use berpengaruh positif pada perceived usefulness penggunaaan software MYOB

\section{Hubungan Perceived Ease of Use, Perceived Usefulness dan Intention of Use}

Pengguna yang merasa bahwa suatu sistem

informasi mudah dalam penggunaannya, akan cenderung lebih tertarik untuk mencoba 
menggunakan sistem tersebut dibandingkan dengan individu yang sebaliknya (Davis, 1989). Selain itu, faktor lain yang meningkatkan kecenderungan individu untuk menggunakan suatu sistem informasi adalah persepsi mengenai manfaat teknologi tersebut. Pengguna yang merasa bahwa suatu sistem informasi akan mendatangkan manfaat, akan cenderung memiliki keinginan lebih untuk menggunakan sistem informasi tersebut (Klopping dan McKinney, 2004). Berdasarkan argument dan penelitian terdahulu, maka hipotesis dalam penelitian ini adalah:

$\mathbf{H}_{2}$ : Perceived ease of use berpengaruh positif pada intention of use software MYOB

$\mathbf{H}_{3}$ : Perceived usefulness berpengaruh positif pada intention of use software MYOB

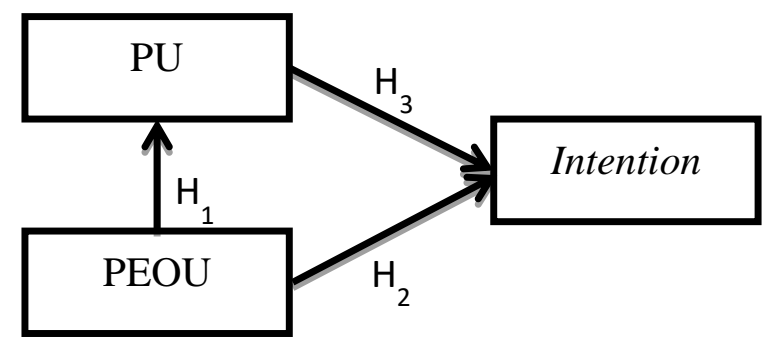

\section{Model Penelitian}

\section{METODE PENELITIAN}

\section{Sampel dan Data}

Sampel dalam penelitian ini adalah akuntan muda di Kabupaten Kebumen dengan proxy mahasiswa dan alumni akuntansi D3 STIE Putra Bangsa Kebumen. Teknik pengambilan sampel dilakukan metode purposive sampling dengan kriteria telah mengambil mata kuliah Komputer Akuntansi dengan pertimbangan bahwa responden pernah menggunakan software MYOB. Pengumpulan data dalam penelitian ini menggunakan survey dengan cara menyebar kuisioner secara online dengan bantuan google.form. Sampel yang digunakan dalam penelitian ini berjumlah 47 responden yang terdiri dari 41 responden perempuan dan 6 responden laki-laki

Penelitian ini menggunakan google form sebagai media untuk menyebarkan kuisiner penelitian, oleh karena itu, tingkat respon dalam penelitian ini tidak dapat ditentukan

\section{Pengukuran Variabel}

Variabel perceived ease of use, perceived usefulness dan intention of use menggunakan instrument yang dikembangkan oleh Davis (1989) yang terdiri dari 5 item pertanyaan untuk perceived ease of use; 6 item pertanyaan untuk perceived usefulness; dan 3 item pertanyaan untuk intention to use. Instrumen berupa kuisioner diukur dengan menggunakan skala likert 5 poin.

\section{HASIL PENELITIAN .}

\section{Uji Validitas dan Reliabilitas}

Hasil uji validitas dan reliabilitas menunjukkan bahwa instrumen penelitian sudah valid dan .reliabel dapat dilihat pada tabel 1

Hasil pada tabel 1, diketahui bahwa corrected item-total correlation menunjukkan angka $>0,3$ untuk setiap indikator, hal ini berarti bahwa standar minimal uji validitas telah terpenuhi. Uji reliabilitas mensyaratkan cronbach's alpha $>0,7$, pada tabel dapat dilihat bahwa semua indikator sudah reliabel.

Tabel 1

Validitas dan Reliabilitas

\begin{tabular}{|l|r|r|r|r|}
\hline & $\begin{array}{c}\text { Scale Mean } \\
\text { if Item } \\
\text { Deleted }\end{array}$ & $\begin{array}{c}\text { Scale } \\
\text { Variance if } \\
\text { Item Deleted }\end{array}$ & $\begin{array}{r}\text { Corrected } \\
\text { Item-Total } \\
\text { Correlation }\end{array}$ & $\begin{array}{r}\text { Cronbach } \\
\text { s Alpha if } \\
\text { Item } \\
\text { Deleted }\end{array}$ \\
\hline PE_1 & 48.91 & 63.949 & .749 & .937 \\
PE_2 & 49.13 & 62.940 & .671 & .939 \\
PE_3 & 49.13 & 63.896 & .693 & .938 \\
PE_4 & 49.32 & 62.048 & .800 & .935 \\
PE_5 & 49.51 & 61.560 & .630 & .942 \\
PU_1 & 48.91 & 63.862 & .724 & .938 \\
PU_2 & 48.81 & 65.289 & .650 & .940 \\
PU_3 & 49.28 & 62.683 & .783 & .936 \\
\hline
\end{tabular}




\begin{tabular}{|l|l|l|l|l|}
\hline PU_4 & 49.09 & 65.123 & .699 & .939 \\
PU_5 & 49.06 & 64.061 & .739 & .937 \\
PU_6 & 49.04 & 62.650 & .811 & .935 \\
\hline IU_1 & 49.06 & 62.757 & .707 & .938 \\
\hline IU_2 & 49.43 & 62.685 & .692 & .939 \\
\hline IU_3 & 49.21 & 63.128 & .704 & .938 \\
\hline
\end{tabular}

\section{Pengujian Hipotesis}

Pengujian hipotesis dalam penelitian ini dilakukan dengan menggunakan software SPSS, dengan pengujian asumsi klasik sebelumnya. Pengujian hipotesis dilakukan melalui dua tahapan. Tahap pertama menguji pengaruh perceived ease of use terhadap perceived usefulness menggunakan regresi sederhana. Hasil pengujian dapat dilihat pada tabel berikut

Tabel 2

\section{Ringkasan Pengujian Hipotesis}

\begin{tabular}{|c|c|c|c|}
\hline Keterangan & B & Sig & Kesimpulan \\
\hline $\begin{array}{c}\text { PEOU } \\
\rightarrow \text { PU }\end{array}$ & 0,828 & 0,000 & Terdukung \\
\hline
\end{tabular}

Hipotesis pertama dalam penelitian ini menyatakan bahwa perceived ease of use berpengaruh positif pada perceived usefulness. Tabel 2 menunjukkan koefisien sebesar 0,828 dan nilai signifikansi sebesar 0,000 (di bawah 0,05), sehingga dapat disimpulkan bahwa hipotesis pertama terdukung.

\section{Tabel 3}

\section{Ringkasan Pengujian Hipotesis}

\begin{tabular}{|c|c|c|c|}
\hline Keterangan & B & Sig & Kesimpulan \\
\hline $\begin{array}{c}\text { PEOU } \\
\rightarrow \mathrm{IU}\end{array}$ & 0,091 & 0,419 & $\begin{array}{c}\text { Tidak } \\
\text { terdukung }\end{array}$ \\
\hline $\mathrm{PU} \rightarrow \mathrm{IU}$ & 0,400 & 0,001 & Terdukung \\
\hline
\end{tabular}

Hipotesis kedua dalam penelitian ini menyatakan bahwa perceived ease of use berpengaruh positif pada intention to use. Tabel
3 menunjukkan koefisien sebesar 0,091 dan nilai signifikansi sebesar 0,419 (di atas 0,05), sehingga dapat disimpulkan bahwa hipotesis kedua tidak dapat terdukung.

Hipotesis ketiga dalam penelitian ini menyatakan bahwa perceived usefulness berpengaruh positif pada intention to use. Tabel 3 menunjukkan koefisien sebesar 0,400 dan nilai signifikansi sebesar 0,001 (di bawah 0,05 ), sehingga dapat disimpulkan bahwa hipotesis ketiga terdukung.

\section{KESIMPULAN}

Penelitian ini bertujuan untuk menguji keberterimaan akuntan muda terhadap software MYOB dengan menggunakan pendekatan TAM (Technology Acceptance Model). Hasil penelitian menunjukkan bahwa akuntan muda di Kabupaten Kebumen cenderung menerima sistem informasi apabila mereka beranggapan bahwa sistem tersebut mendatangkan manfaat, namun demikian persepsi kemudahan penggunaan tidak menjadi penentu keinginan penggunaan suatu sistem informasi.

\section{KETERBATASAN DAN SARAN}

Penelitian ini memiliki beberapa keterbatasan, diantaranya responden dalam penelitian ini merupakan proxy dari akuntan, untuk penelitian selanjutnya dapat dilakukan pada responden akuntan yang sesungguhnya. Selain itu, model TAM yang digunakan dalam penelitian ini merupakan model yang sangat sederhana, untuk penelitian selanjutnya dapat mengembangkan model dengan menambahkankan variabel lain misalnya attitude.

\section{DAFTAR PUSTAKA}

Bodnar, G. dan W. Hopwood. 1995. Accounting Information System. 6th Edition. Englewood Cliffs. New Jersey: Prentice Hall International Inc.

Davis, F. D. 1989. Perceived Usefulness, Perceived Ease of Use, and User Acceptance of Information Technology. 
Management Information System Quartely, September: 319-358.

Dewayanto, T. 2011. Analisis Penerimaan Komputer Mikro dengan Menggunakan Technology Acceptance Model (TAM) pada Kantor Akuntan Publik (KAP) di Jawa Tengah. Jurnal STIE Semarang, Vol. 3 (2): 1-27.

Göğüş, Ç. dan G. Özer. 2014. The Role of Technology Acceptance Model Antecedents and Switching Cost on Accounting Software Use. Academy of Information and Management Science Journal, Vol. 17 (1): 1-24.

Juniarti. 2001. Technology Acceptance Model (TAM) dan Theory Planned Behavior (TPB), Aplikasinya dalam Penggunaan Sofware Audit oleh Auditor. Jurnal Riset Akuntansi Indonesia, Vol. 4 (3): 332-354.

Klopping, I.M. and E. McKinney. 2004. Extending the Technology Acceptance Model and Task-Technology Fit Model to Consumer E-Commerce. Information Technology, Learning, and Performance Journal. Vol. 22 (1), Spring: 35-47.

Lucyanda, J. 2010. Pengujian Technology Acceptance Model (TAM) dan Theory Planned Behaviour. Jurnal Riset Akuntansi dan Komputerisasi Akuntansi, Vol. 2 Agustus: 1-14.

Nasution, F.N. 2004. Penggunaan Teknologi Berdasarkan Aspek Perilaku (Behavioral Aspect). USU Digital Library: 1-10.

Rustiana. 2006. Studi Model Penerimaan Tehnologi (Technology Acceptance Model) Novice Accountant. KINERJA, Vol. 10 (1): 40-49.

Saade, R. G., Fassil N. dan W. Tan. 2007. Viability of the "Technology Acceptance Model" in Multimedia Learning Environment: A Comparative Study. Interdiciplinary Journal of Knowledge and Learning Objects. Vol 3: 175-183.

Surendran, P. 2012. Theory Acceptance Model: A Survey of Literature. International
Journal of Business and Social Research, Vol. 2 (4): 175-178.

Tangke, N. 2004. Analisa Penerimaan Penerapan Teknik Audit Berbantuan Komputer (TABK) dengan Menggunakan Technology Acceptance Model (TAM) pada Badan Pemeriksaan Keuangan (BPK) RI. Jurnal Akuntansi dan Keuangan. Vol. 6 (1), Mei: 10-28.

Venkatesh, V. dan F. D. Davis. 2000. A Theoritical Extension of the Thechnology Acceptance Model: Four Longitudinal Field Studies. Management Sciences, Vol. 46 (2), Februari: 186-204.

Winarni, R. dan D. Rahmawati. 2015. Pengaruh Karakteristik Tipe Kepribadian dan IPK Terhadap Kecemasan Berkomputer Mahasiswa Akuntansi dalam Menggunakan Software Akuntansi dengan Locus of Control sebagai Variabel Moderasi. Jurnal Nominal, Vol. 4 (1): 116. 